\title{
West Nile Virus and Mosquito Control
}

\author{
David Pimentel \\ Cornell University, Ithaca, New York, U.S.A.
}

\section{INTRODUCTION}

The West Nile virus, which causes serious encephalitis in Americans, was introduced from Africa into northeastern United States in 1999. No one knows exactly how the virus was transported here, but with rapid air travel and large numbers of people and goods being moved throughout the world, the West Nile virus could have been carried to the United States by an infected bird, person, or even by a mosquito.

By the year 2003, the Centers for Disease Control (CDC) reported there were 8900 reported human infections of the West Nile disease with 218 deaths, with many of the infections and deaths occurring in Ohio. The rate of infections and deaths is running significantly ahead of last year, with most of the infections and deaths occurring in Colorado where the incidence has increased from only 14 infections in 2002 to 635 West Nile infections by August 2003.

\section{BIRD RESERVOIRS}

The prime reservoir of West Nile is the bird population. At least 125 species of birds have been reported infected with West Nile, ${ }^{[1]}$ with crows, blue jays, sparrows, hawks, eagles, and others identified as reservoirs. Birds appear to be especially susceptible to the virus and are more likely to die of an infection than are humans. In some localities crows and blue jays have all but disappeared. Estimates are that 20,000 birds were killed last year from West Nile in the United States. Because birds travel long distances in their seasonal migrations, infected birds spread the disease to humans, horses, and other animals. Mosquitoes obtain the virus mostly from infected birds and in turn infect humans by biting them.

\section{MOSQUITO VECTORS}

In the Northeast, the prime mosquito vector between birds and humans is Culex pipens, the house mosquito. In New York and New Jersey, when 32,000 mosquitoes were examined by the $\mathrm{CDC},{ }^{[2]}$ the great majority associated with West Nile were Culex pipens. ${ }^{[3]}$ In Colorado, the prime mosquito vectors are Culex tarsalis and Culex pipens. Other mosquito species capable of transmitting the West Nile virus include other Culex species, Anopheles sp, Coquilletidia sp., Ochlerotatus spp., and Psorophora sp.

Male mosquitoes feed primarily on nectar and do not bite humans. The female mosquito requires a blood meal and when she bites an infected bird she then transmits the West Nile virus to humans by biting them.

The life cycle of Culex mosquito is about 14 days at temperatures of about $21^{\circ} \mathrm{C}\left(70^{\circ} \mathrm{F}\right)$. The female obtains her blood meal from birds, humans, and other animals. She mates either before or after her blood meal. Then she lays about 250 eggs in pools of water, including bird baths, flower pots, tin cans, old tires, as well as other pools of collected water. The egg stage lasts 1 to 2 days and the emerging larvae feed on algae, bacteria, and other organic matter in the water. The larval stage lasts 7 days followed by the pupal stage that lasts 2 to 3 days. Adult mosquitoes emerge from the pupae and the life cycle begins again. The adult mosquitoes normally live a week or two, but also hibernate in protected locations during the winter (Fig. 1).

Adult mosquitoes are not strong fliers and usually travel only a few hundred feet from the place of emergence. They may be carried by the wind several miles. In general, when the wind is blowing above $5 \mathrm{mph}$ they will not fly. Female mosquitoes feed most often during the evening and morning.

\section{MOSQUITO LARVAL CONTROL}

The CDC advises that mosquito control should focus primarily on mosquito larval control and secondarily on the less efficient adulticiding. ${ }^{[4]}$ Effective larval control curtails the supply of adult mosquitoes.

In aquatic habitats, mosquito larvae have many predators, but few parasites. The predators include damselfly larvae, back swimmers, dragonfly larvae, water boatman, dytiscid beetles, frogs, fishes, and salamanders. However, none of these predators is effective because they usually inhabit permanent water bodies, whereas most mosquito larvae live in temporary pools of water. 


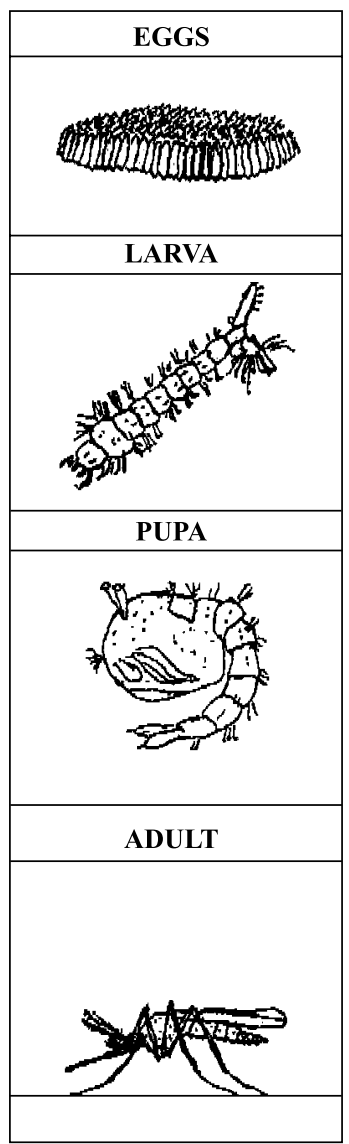

Fig. 1 Culex mosquito eggs, larva, pupa, and adult female.

Although mosquito larvae can be killed by bacteria, protozoans, nematodes, and fungi, none of these provides control for large mosquito populations. One exception, a strain of Baccilus thringiensis isrraeliensis or BT has proven effective. Various commercial formulations of this bacterium are available for application to ponds and pools where larvae are found.

In addition to eliminating all mosquito breeding sites, such as bird baths, flower pots, tires, ponds, and pools of water, such breeding habitats may also be treated, provided some water remains in them. BT is an effective larvacide that is safe for humans and pests, but it may kill some beneficial insects in water bodies.

In some small bodies of water, a thin layer of light oil can be spread over the surface. This will kill both mosquito larvae and pupae in the water. However, the oil also may have negative impacts on small fish and arthropods in the water.

Most insecticides are banned from water bodies because they are highly toxic to most aquatic organisms, such as fish, frogs, salamanders, and arthropods.

\section{ADULT MOSQUITO CONTROL}

Instead of focusing control efforts on larval mosquitoes as suggested by CDC, most homeowners and municipalities focus on adult mosquito control.

\section{Adult Mosquito Control with Predators}

Adult mosquitoes have relatively few predators because they are so small and not a large meal for a predator. Dragonflies, bats, and small birds such as purple martins feed on a few adult mosquitoes, but none of these animals can be counted on to control large populations of adult mosquitoes.

\section{ULTRALOW VOLUME SPRAYING}

Before municipalities spray for mosquitoes, the mosquito population should be measured for 5 days before spraying and 5 days after spraying using various mosquito traps. Such data will assist the government officials to determine whether the several thousand or millions of dollars spent in spraying was effective.

Homeowners should require warning $72 \mathrm{hr}$ in advance of community spraying. During spraying, the windows and doors should be closed and the people should stay inside away from the insecticide spray.

When many West Nile infected birds are found and the mosquito population is relatively abundant, municipalities are often pressured into spraying pyrethroid insecticides for mosquito control. This spraying is carried out using trucks mounted with ultralow volume (ULV) sprayers. The insecticide spray produced from these units is like a smoke or fine mist and is carried downwind. Even assuming that the spraying is carried out in the evening when wind is minimal, the spray is carried downwind in an open area, for instance, on a golf course. Downwind, from 150 to $300 \mathrm{ft}$ and at $3 \mathrm{ft}$ height, the mosquito kill will range from $25 \%$ to $75 \%{ }^{[5]}$ However, ZERO mosquitoes will be killed upwind by the insecticide spray. Thus the average upwind and downwind kill is only $21 \%$ to $45 \%$. Note, the insecticide spray does not penetrate buildings, and mosquitoes behind buildings are not killed. Further, dense vegetation hinders spray treatment and desired mosquito control. For example, downwind in a dense stand of trees, mosquito kill is reported to be only $34 \%$ to $58 \%{ }^{[5]}$

For effective mosquito control, at least $90 \%$ of the adults must be killed. Only a few scientific studies of the effectiveness of spraying for mosquito control have been reported. These results are relatively discouraging. For 
example, in Greenwich, CT, only a 34\% mosquito population reduction was reported after ground spraying, and in Houston, TX, only a $30 \%$ reduction occurred after spraying. ${ }^{[6]}$ Then in Cicero Swamp, FL, populations of disease-carrying mosquito populations increased 15-fold after spraying, ${ }^{[6]}$ when the mosquito population was measured 11 days after spraying. However, it is doubtful that the insecticide spray caused the increase in the mosquito population, but clearly the insecticide provided insufficient adult mosquito control.

\section{Aerial ULV Spraying}

The aerial application of insecticides for adult mosquito control has some advantages over ground applications. Reports on the effectiveness of aerial ULV spraying range from $42 \%$ to $93 \% .^{[7,8]}$ However, using ULV aerial equipment results in only $10 \%$ to $25 \%$ of the insecticide reaching the target area, whereas up to $90 \%$ drifts away from the target into the environment at large. ${ }^{[9,10]}$ Aerial application covers a larger area faster than the ground application equipment, but it is more expensive than ground application, costing from $\$ 250$ to $\$ 1000$ per hour (truck spraying costs from $\$ 150$ to $\$ 250$ per hour). Also to be considered are the serious public health and environmental problems associated with the application of insecticides from aircraft. ${ }^{[11]}$

\section{Insecticide Effectiveness in Reaching Target Mosquitoes}

With ULV spraying, the spray particles are minute and measure from 7 to $22 \mu \mathrm{m}$. The lethal dose of a pyrethroid insecticide is one particle 18 to $20 \mu \mathrm{m}$. Based on the fact that many billions of spray droplets are produced per kilogram of insecticide for both ground and aerial spraying, less than $0.0001 \%$ of the insecticide applied is reaching the target mosquitoes. ${ }^{[12]}$ Thus by both ground and aerial application $99.999 \%$ of the insecticide spreads into the environment, when it can cause public health and other environmental problems.

Because many adult mosquitoes remain after spraying and more adult mosquitoes will emerge, if the mosquito larvae are not controlled, then insecticide spraying is required every 7 days. Costs of spraying every 7 days are prohibitive.

\section{PERSONAL PROTECTION}

Homeowners should drain standing water in pools, gutters, and flower pots in the yard. Water in bird baths and wading pools should be changed every 3 days. If outdoors during dawn or dusk when mosquitoes are most abundant and the wind is not blowing, then long pants and a long-sleeve shirt made of heavy material, such as denim, should be worn. Adult mosquitoes easily bite through a light T-shirt.

Various adult mosquito traps and zappers are sold to homeowners for control, but rarely do these units provide continuous satisfactory control of mosquitoes. ${ }^{[13]}$ While outside, homeowners may use an insecticide fogger or can of insecticide spray for temporary control of mosquitoes. However, if the wind is blowing sufficiently strong ( $5 \mathrm{mph}$ or stronger), the mosquitoes will not be a problem because the mosquitoes will not fly in the wind.

Of the numerous chemical repellants, the most popular is the pesticide, DEET. DEET should be applied only to the outer layer of heavy clothes. The chemical should only be used, if there is a serious West Nile threat. DEET has been known to cause rashes, restlessness, lethargy, confusion, slurred speech, clumsiness, seizures, and in a few cases death. ${ }^{[14]}$ For some individuals, the DEET pesticide is reported to cause allergic reactions and may interfere with the immune and endocrine systems for some people.

Located on a patio or other small area, a large fan blowing air about $5 \mathrm{mph}$ or higher will discourage the presence of mosquitoes.

\section{CONCLUSION}

West Nile virus is a health hazard to humans, birds, horses, and other animals. Culex mosquitoes are important vectors in the United States. The prime method of control is the elimination of the breeding habitats for larval mosquitoes, such as water accumulating in bird baths, flower pots, old tires, and other containers.

Widespread ULV spraying from ground equipment or aircraft for control of mosquitoes and West Nile virus is relatively ineffective, costly, and has been associated with environmental and public health risks.

During the evening and early morning, repellants can protect humans from mosquito bites. However, the pesticide DEET and related chemicals should not be applied directly to the skin of children or adults, because they pose serious public health risks.

\section{REFERENCES}

1. Environmental Defense. West Nile Virus on the Rise, Threatening Humans and Wildlife; Environmental Defense: New York, 2003. http://www.environmentaldefense.org/ article.cfm?ContentID =2871 (8/14/03). 
2. CDC. West Nile Virus: Statistics, Surveillance, and Control; Centers for Disease Control: Atlanta, 2002. http://www.cdc.gov/ncidod/dvbid/westnile/surv\&controlCaseCount02.htm (8/17/03).

3. Nasci, R.S.; White, D.J.; Stirling, H.; Oliver, J.O.; Daniels, T.J.; Falco, R.C.; Campbell, S.; Crans, W.J.; Savage, H.M.; Lanciotti, R.S.; Moore, C.G.; Godsey, M.S.; Gottried, K.L.; Mitchell, C.J. Emerging Infectious Diseases; Communicable Disease Center: Atlanta, 2001; Vol. 7. Past Issue. No. 4, Jul-Aug 2001. 10 pp.

4. West Nile Control. West Nile Virus and Mosquito Control Practices; 2002. http://skipper.physics.sunyb.edu/ mosquito/mosquito2/Mosquito2.htm (8/16/03).

5. Mount, G.A. A critical review of ultralow-volume aerosols of insecticide applied with vehicle-mounted generators for adult mosquito control. J. Am. Mosq. Control Assoc. 1998, 14 (3), 305-334.

6. Outcome. Outcome Studies: Control Efforts for West Nile Virus and Mosquito Population; 2003. http://www.ccheinfo.com/pdf/cche-wnv_outcome_studies.pdf (8/13/03).

7. Andis, M.D.; Sackett, S.R.; Carrol, M.K.; Bordes, E.S. Strategies for the emergency control of arboviral epidemics in New Orleans. J. Am. Mosq. Control Assoc. 1987, 3 (2), $125-130$.
8. Williams, R.E.; Knapp, F.W.; Clarke, J.L. Aerial insecticide applications for control of adult mosquitoes in the Ohio River Basin USA. Mosq. News 1979, 39 (3), 622-626.

9. Bird, S.L.; Esterly, D.M.; Perry, S.G. Atmospheric pollutants and trace gases. J. Environ. Qual. 1996, 25, 10951104.

10. Pimentel, D.; McLaughlin, L.; Zepp, A.; Lakitan, B.; Kraus, T.; Kleinman, P.; Vancini, F.; Roach, W.J.; Graap, E.; Keeton, W.S.; Selig, G. Environmental and Economic Impacts of Reducing Agricultural Pesticide Use. In Pesticide Question: Environment, Economics and Ethics; Pimentel, D., Ed.; Chapman and Hall: New York, 1993; 223-278.

11. Pimentel, D. Environmental and Economic Costs of the Application of Pesticides in the U.S. In Environment, Development and Sustainability; in press.

12. Pimentel, D. Amounts of pesticides reaching target pests: Environmental impacts and ethics. J. Agric. Environ. Ethics 1995, 8 (1), 17-29.

13. Mosquito Buzz. Mosquito Magnet: Competitive Comparison Chart; 2003. http://www.mosquitobuzz.com/control/ comparisonchart2.html (8/16/03).

14. Marshall, L. Physicians urge caution with DEET. Daily Camera 2003, 4A. 


\section{Request Permission or Order Reprints Instantly!}

Interested in copying and sharing this article? In most cases, U.S. Copyright Law requires that you get permission from the article's rightsholder before using copyrighted content.

All information and materials found in this article, including but not limited to text, trademarks, patents, logos, graphics and images (the "Materials"), are the copyrighted works and other forms of intellectual property of Marcel Dekker, Inc., or its licensors. All rights not expressly granted are reserved.

Get permission to lawfully reproduce and distribute the Materials or order reprints quickly and painlessly. Simply click on the "Request Permission/ Order Reprints" link below and follow the instructions. Visit the U.S. Copyright Office for information on Fair Use limitations of U.S. copyright law. Please refer to The Association of American Publishers' (AAP) website for guidelines on Fair Use in the Classroom.

The Materials are for your personal use only and cannot be reformatted, reposted, resold or distributed by electronic means or otherwise without permission from Marcel Dekker, Inc. Marcel Dekker, Inc. grants you the limited right to display the Materials only on your personal computer or personal wireless device, and to copy and download single copies of such Materials provided that any copyright, trademark or other notice appearing on such Materials is also retained by, displayed, copied or downloaded as part of the Materials and is not removed or obscured, and provided you do not edit, modify, alter or enhance the Materials. Please refer to our Website User Agreement for more details.

\section{Request Permission/Order Reprints}

Reprints of this article can also be ordered at http://www.dekker.com/servlet/product/DOI/101081EEPM120009995 